\title{
Research Article: Functional polymorphism for crtRB1 gene loci in tropical maize (Zea mays L.) inbred lines
}

Article Chronicle : Received :

12.07.2017;

Accepted :

25.07.2017

KeY Words:

Tropical maize, Provitamin A, $\beta$ carotene, crtRB1

Author for correspondence :

\section{SHRIKANT}

YANKANCHI

Department of

Molecular Biology and

Agricultural

Biotechnology, College

of Agriculture,

University of

Agricultural Sciences,

RAICHUR (KARNATAKA)

INDIA

Email : shrikantyan

kanchi@gmail.com

See end of the article for

authors' affiliations

\author{
SHRIKANT YANKANCHI, P.M. SALIMATH, AYYANGOUDA PATIL, \\ PERVEZ H. ZAIDI, B. KISAN, PRAKASH H. KUCHANUR, M.T. VINAYAN \\ AND K. SEETHARAM
}

SUMMARY : Maize (Zea mays L.) is an important cropknown for its carotenoid diversity among cereals which accumulates significant levels of proA (provitamin A) and non-proA carotenoids its kernels. The proA components of maize endosperm promises to solve themajor global problem VAD (Vitamin A deficiency). Among several genes involved in $\beta$-carotene biosynthetic pathway, crtRB1 is very important gene associated with three polymorphisms viz., 5 'TE, In Del4 and 3'TE (Transposable Element) responsible for variation in carotenoid levels in maize endosperm. Due to insertion of TE at 3' UTR (Un Translated Region), crtRB 1 again exhibits polymorphism with 3 alleles, however, only allele 1(favourable allele; 543bp amplicon) of this crtRB1-3'TE gene will double the $\beta$-carotene concentration in maize endosperm and allele 2 and 3 termed as unfavourable. This study was undertaken to find out the allelic difference for crtRB1gene loci. Totally 228 tropical maize inbred lines were screened for allele 1 of crtRB1 gene using crtRB1-3'TE gene specific markers. Among 228 in breds, 226 inbreds showed the presence of allele 2 and the two inbredsVL1016247 and VL1016213 possessed both alleles 1 and 2 which are found to be heterozygous for crtRB1loci. This study indicated the possible use of (VL1016247 and VL1016213) these two inbreds for developing provitaminA (proA) rich maize hybrids using marker assisted selection (MAS).

How to cite this article : Yankanchi, Shrikant, Salimath, P. M., Patil, Ayyangouda, Zaidi, Pervez H., Kisan, B., Kuchanur, Prakash H., Vinayan M.T. and Seetharam, K. (2017). Functional polymorphism for crtRB1 gene loci in tropical maize (Zea mays L.) inbred lines. Agric. Update, 12(TECHSEAR-2) : 583-588; DOI: 10.15740/HAS/ AU/12.TECHSEAR(2)2017/583-588. 